\title{
Foreign Submarines in Swedish Waters: The Erosion of an International Norm.*
}

\author{
Roma Sadurska $\uparrow$
}

\section{Problem}

It is a well-settled principle of international law that the appropriate responses of a coastal state to an intrusion by a foreign submarine into its internal waters or a non-innocent passage through its territorial sea are limited to requiring the intruding ship to leave its waters and to making a protest to the ship's flag state. This norm is related to the international principle of jurisdictional immunity of foreign warships, a principle long deemed vital to the public order of the oceans.

Increasing violations of Swedish internal waters by unauthorized foreign submarines, typified by the incident described in this Study, induced Sweden to change its policy in ways not consonant with the existing international position. Under this new policy, contained in a recently-enacted Swedish ordinance, an intruding submarine found submerged in internal waters is to be forced to the surface, by armed force if necessary, and brought to a Swedish port for investigation and further action. A submerged submarine found in Swedish territorial waters is to be turned back to the high seas, regardless of the purpose of its passage, by armed force if necessary.

This policy received the express approval of several countries, and the apparent tolerance of others. No protests, so far, have been voiced. The Swedish actions, coupled with the apparent acquiescence of the international community, mark the beginning of a potentially serious erosion of the international norm proscribing use of force in dealing with intruding submarines, without any explicit appraisal of the consequences of such erosion by the international community.

\section{Facts}

The incident described in this Study consists of a sequence of two discrete events, one at Karlskrona and the other at Harsfjarden. ${ }^{1}$

* I gratefully acknowledge the comments and criticisms of Professor Ingemar Dorfer of the Swedish National Defense Research Institute. The views expressed herein, however, are my own and are not necessarily representative of the views of Professor Dorfer.

$\dagger$ Research Associate, University of New South Wales; LL.M., Yale Law School, 1984; Ph.D., Polish Academy of Sciences, 1978; LL.M., Warsaw University, 1973.

1. The events at Karlskrona and Harsfjarden are only two chapters in a long history of 


\section{A. The Karlskrona Event}

On October 27, 1981, a Soviet diesel submarine ran aground in Gasefjarden Bay, a restricted military area in the immediate vicinity of the main Swedish naval base at Karlskrona. ${ }^{2}$ The vessel was spotted the next day by a fishing boat, and ships from the Karlskrona base hurried to the scene and surrounded the grounded vessel. ${ }^{3}$

The submarine's commander stated that the gyrocompass had failed, causing a navigational error. The Swedish authorities, however, did not believe this statement $t^{4}$ and immediately delivered a protest to the Soviet Ambassador. ${ }^{5}$ The Swedish public, fueled by the media, also made angry protests against the event and its implications for Sweden's ability to protect its national security. ${ }^{6}$ The Swedish Government announced that Sweden would salvage the submarine, thereby rejecting the U.S.S.R.'s demand that Soviet tugs be allowed to refloat the submarine, ${ }^{7}$ and stated that return of the submarine to the Soviet Union would await the results of an investigation to be undertaken by the Commander-in-Chief of the Swedish Armed Forces. ${ }^{8}$ As preliminary steps towards return, Sweden requested an apology from the Soviet Union, and at least tacit acceptance of the investigation to be conducted by Swedish authorities.9

On October 29, the Soviet Union agreed to the Swedish salvage opera-

intrusions into Swedish waters by foreign submarines. Between 1962 and 1980 Swedish waters were violated by foreign submarines at least 93 times, with the highest number of trespasses in a single year not exceeding nine. In 1981, the number of violations increased only slightly to ten, but in the first eight months of 1982 the number of reported intrusions jumped to forty. Submarine Defense Comm'N, Countering the Submarine Threat app. 2 (S.O.U. No. $13,1983)$ [hereinafter cited as COMMISSION REPORT].

2. Gasefjarden Bay is located in the Karlskrona Archipelago on the southeast coast of Sweden. For the Swedish account of events and the statement of Swedish policy, see Theutenberg, $U 137$ - Folkratt och neutralitetspolitik $i$ tillampning, KUN GL. KRIGSVETENSKAPSAKADEMIENS HANDLINGAR OCH TIDSKRIFT, No. 2, at 85, et seq. (1982) (on file with the Yale Journal of International Law).

3. Svenska Dagbladet, Oct. 29, 1981; Frankfurter Allgemeine, Oct. 30, 1981.

4. Radio Stockholm Domestic Service [hereinafter cited as RSDS], Oct. 28, 1981; Foreign Broadcast Information Service [hereinafter cited as FBIS] (W. Europe), Oct. 29, 1981, at 2 (interview with O. Ullsten, Swedish Minister of Foreign Affairs); accord, Svenska Dagbladet, Oct. 29, 1981.

5. RSDS, Oct. 28, 1981; FBIS, supra note 4.

6. See, e.g., Dagens Nyheter, Oct. 29, 1981 (editorial calling for interrogation of the Soviet submarine's commander).

7. Radio Stockholm International Service [hereinafter cited as RSIS], Oct. 29, 1981 (Press conference of the Swedish Minister of Foreign Affairs).

8. RSDS, Oct. 29, 1981; FBIS (W. Europe), Oct. 30, 1981, at 7 (text of the Government's communiqué).

9. Radio Stockholm to Europe and the Middle East, Oct. 31, 1981. 
tion, ${ }^{10}$ and on October 30 an apology was conveyed by the Soviet Ambassador stating that the Soviet Union regretted that the submarine had entered Swedish territorial waters and trespassed in a restricted military area. ${ }^{11}$ Although the Soviet government did not explain why the submarine had gone so far into Swedish waters, the Swedish Minister of Foreign Affairs described the apology as significant, particularly in light of the Soviet Union's refusal to apologize for similar intrusions in the past, and expressed the view that the apology demonstrated the Soviet Union's willingness to cooperate. ${ }^{12}$

Despite this official optimism, however, the Soviet Union never acquiesced in a full-scale investigation, ${ }^{13}$ although it finally did agree to allow Sweden to conduct a limited inspection of the vessel and to interrogate the Soviet submarine commander and crew on board a Swedish vessel in the presence of representatives from the Soviet Embassy. ${ }^{14}$ After reaching this agreement on November 2, Swedish tugs pulled the Soviet submarine from the mud to a safer anchorage within Swedish waters. ${ }^{15}$

The testimony of the commander and crew supported the initial Soviet statement that the intrusion was caused by navigational error due to compass failure. The Swedish Navy officer who examined the submarine's log book reported, however, that crucial information had been altered by the crew and that the navigational instruments were in good order. ${ }^{16}$ The Swedish investigators were not allowed to inspect the forward part of the submarine where torpedoes are usually carried. On November 5, however, the Swedish authorities announced that experts from the Research Institute of Swedish National Defense, who had examined the submarine externally, were able to establish the presence of Uranium-238 on board, from which they concluded that torpedoes with nuclear warheads were present on the Soviet submarine. ${ }^{17}$

The Swedish Government sent the Soviet authorities a "sharply worded protest" demanding to know whether the submarine was carrying nuclear arms. ${ }^{18}$ The answer was utterly equivocal: the Soviet government stated that "the submarine carries, as do all naval vessels at sea, the necessary weapons and ammunition." 19

10. RSIS, Oct. 30, 1981; FBIS, supra note 8, at 8.

11. Radio Stockholm to Europe and the Middle East, Oct. 31, 1981.

12. Id.

13. RSIS, Oct. 30, 1981; FBIS, supra note 8, at 8.

14. RSDS, Nov. 2, 1981; FBIS (W. Europe), Nov. 2, 1981, at 3.

15. 1981 FACTS ON FILE [hereinafter cited as 1981 FACTS], 804 A2.

16. RSDS, Nov. 11, 1981.

17. RSDS, Nov. 5, 1981; FBIS (W. Europe), Nov. 6, 1981, at 2.

18. 1981 FACTS, supra note 15 , at 840 D, E3.

19. Id. 
At this point, Swedish authorities decided to close the investigation, and the submarine was returned to the Soviets on November 6.20

\section{B. The Harsfjarden Event}

On October 1, 1982, nearly a year after the episode at Karlskrona, Swedish naval units once again were put on a state of alert. A foreign submarine had been spotted in Harsfjarden, near the top-secret Musko naval base. A depth charge was dropped from a helicopter and the area was searched by patrol boats and helicopters. The following day the search continued and four further depth charges were dropped. The Navy units placed metal barriers across the two main entrances to Harsfjarden through which conventional submarines might leave the area. The rest of the area (50 square kilometers) was not sealed off, and minisubmarines could have escaped easily from the trap. ${ }^{21}$

On October 3, the search units made sonar contact with a submarine and responded with two depth charges. The next day brought further indications of submarine presence: radar and sonar echoes, air bubbles, and a large oil slick that appeared on the surface after twelve depth charges had been dropped. ${ }^{22}$ During the following two days similar evidence of the presence of a submarine was noticed and twelve further depth charges had been dropped. ${ }^{23}$

On October 6, minesweepers, a submarine rescue vessel, anticraft units, and military police were brought into action in preparation for a mine detonation. The following day the Navy dropped six depth charges outside the northern barrier of Harsfjarden where there were indications of either a breakout from within or an attempt to force through the barrier from the outside. Thereafter, three mines were detonated in the vicinity of Malsten. An internment center was prepared for any rescued crew, and hospitals were alerted to prepare for possible injured seamen who, it was assumed, would be suffering from detonation shock. Swedish Armed Forces were on full alert along the entire coast and prepared for a possible emergency surfacing of the foreign submarine. ${ }^{24}$

The mine detonations, however, produced no results; no evidence of

20. RSIS, Nov. 6, 1981; FBIS, supra note 17 , at 5 . The bill for the salvage operation totaled 1.6 million kroner and was paid by the Soviet Government. Dagens Nyheter, Dec. 23, 1981; RSDS, Mar. 25, 1982.

21. Agence France Press (Stockholm) [hereinafter cited at AFP], Oct. 3, 1982; FBIS (W. Europe), Oct. 4,1982 , at 4 . The first press communique was issued by the Defense Staff on the evening of October 2, 1982. Id.

22. AFP, Oct. 6, 1982.

23. Id.

24. AFP, Oct. 8, 1982. 
wreckage was found by divers or underwater cameras. In the evening, new sonar contacts were obtained outside the northern barrier and in north Mysingen, indicating that a submarine might have escaped from the trap in Harsfjarden. Nevertheless, the search continued both inside and outside the barrier, and on October 9 new controlled mines were laid. The same day, indications of possible submarine presence came from Mamdo (north of Harsfjarden), and two days later from Danziger Gatt (south of Harsfjarden). The latter were particularly strong on October 14, when two depth charges were dropped in Danziger Gatt. The search continued until November 1, during which period there was no further sonar contact. ${ }^{25}$

\section{Conflicting Claims}

\section{A. The Karlskrona Event}

The physical presence of the grounded submarine in Swedish national waters was the only material fact regarding Karlskrona as to which the claimants were in agreement. Each had a different version of the purpose of the submarine's mission, the causes of the accident, and the presence of nuclear weapons on board the submarine.

The Soviets claimed that the submarine, "while making a routine training cruise in the Baltic Sea, went off course in conditions of poor visibility and ran aground."26 The Swedish Government, however, maintained from the outset that the submarine was not performing a mere training task, but rather was engaged in illegal intelligence-gathering. The Swedish Commander-in-Chief, in his report of the Swedish investigation, contended that the Soviet submarine was already in Swedish waters on October 24, 1981, and had carried out exercises for four days inside and outside the territorial sea before it ran aground. ${ }^{27} \mathrm{He}$ also concluded that the submarine was on the surface in Swedish waters at least two hours before it was grounded, and that its crew were aware that they were entering a restricted military area. ${ }^{28}$

The Soviet Government described the charge of illegal activities as "bewildering" and "a distortion of facts." 29 "What sober minded per-

25. COMMISSION REPORT, supra note 1 , at 105 .

26. TASS, Nov. 4, 1981, reprinted in 33 CURRENT Dig. SoviET PRESS, No. 44, at 7 (1981).

27. Svenska Dagbladet, Dec. 19, 1981. The report containing the Commander-in-Chief's final conclusions was classified as secret and only part of it was published in December 1981.

28. Id.

29. 33 CurRent Dig. Soviet Press, No. 45, at 5 (1981) (statement of the Soviet government issued Nov. 11, 1981). 
son," asked the Soviet Government, "to say nothing of military specialists, can suppose that a submarine, in a surface run with its running lights on and operating diesel engines whose noise could be heard for a great distance, at night and in conditions of poor visibility, could engage in such 'activities?"30

It is a puzzling question indeed, and the Swedish Commander-in-Chief had to admit that there were no definite indications of the submarine's presence from radar or radio surveillance. The Report offered as a possible explanation the hypothesis that a radar echo was misinterpreted by the Swedish coast guard. "Therefore, the possibility cannot be excluded that radar surveillance did reveal the submarine, but that this was taken at the time for a merchant ship or a fishing boat. Identification of radar echoes must normally be effected through direct sighting." 31 In other words, the Report indicates that it is conceivable that a foreign submarine could perform illegal activities quite openly without being identified by the Swedish coastal surveillance system.

As noted above, ${ }^{32}$ the parties also disagreed as to the cause of the intrusion. The Soviet authorities consistently maintained that the intrusion was caused by failure of the vessel's navigational instruments, ${ }^{33}$ while the Swedish government alleged that the submarine's navigational instruments were in good working order. ${ }^{34}$ The Swedes did not believe the submarine could have reached its location in the restricted military zone if its navigational instruments had been inoperative, since this required traversal of twelve nautical miles of Swedish territorial waters through the outer Karlskrona archipelago and around dozens of small islands and bays. ${ }^{35}$ The Swedes also pointed to the fact that the submarine did not send any distress signal for seventy-two hours after it had run aground. ${ }^{36}$

Finally, the Swedes asserted that there was a high probability that the Soviet submarine was carrying nuclear warheads. ${ }^{37}$ The Soviets never directly denied this statement, although they did challenge the basis for the

\footnotetext{
30. Id.

31. Svenska Dagbladet, Dec. 19, 1982.

32. See supra notes $4,5 \& 16$ and accompanying text.

33. TASS, Nov. 4, 1981; TASS, Nov. 11, 1981.

34. RSDS, Nov. $11,1981$.

35. Theutenberg, supra note 2, at 101-02.

36. Id. The Soviet Union's statements also did not offer any explanation for the grounding itself, focusing instead on the reasons for the initial intrusion into Swedish waters. The Soviets may have hoped by this tactic to focus attention on the wandering off course of the submarine, thereby avoiding the embarrassing question of its trespass into the restricted military zone. According to the Swedish Report, the grounding occurred because of an error in maneuvering inside the restricted military area when the submarine attempted a rapid and powerful turn that was executed too late. Svenska Dagbladet, Dec. 19, 1982.
}

37. RSDS, Nov. 5, 1981; FBIS, supra note 17, at 2 . 
assertion, dismissing as "absurd" the claims of Swedish nuclear experts that the presence of Uranium-238 made it likely that the submarine was carrying nuclear weapons. ${ }^{38}$ With regard to the actual presence of nuclear weapons, the Soviet Union merely stated that the vessel carried "necessary weapons and ammunition." 39

\section{B. The Harsfjarden Event}

The reconstruction of the dialogue between the Soviet and Swedish governments during and after the Harsfjarden event is difficult. The communication between the two governments resembled a long monologue by Sweden, with only a short, indignant response on the part of the Soviet Union. The Swedish government, embarrassed and under strong internal political pressure to clarify the circumstances of the event, put forward an extensive analysis contained in the Report of the Submarine Defense Commission ("Commission Report"). Because no direct evidence of the presence of Soviet submarines was offered, the official Soviet media simply dismissed all accusations as propaganda and falsifications without entering into any factual or legal argument.

The Soviet Union's indignant response was prompted by Swedish allegations that the submarines involved at Harsfjarden were Soviet submarines. During the event itself, the Swedes had been careful to refrain from making allegations regarding the nationality of the suspected submarines, and this discretion no doubt helped repair Swedish-Soviet relations, damaged by the occurrences at Karlskrona. ${ }^{40}$

The situation changed abruptly, however, with the publication of the Commission Report in April 1983. The Commission concluded that the submarines that had violated Swedish internal waters in September and October 1982 belonged to the Soviet Union. ${ }^{41}$ In response, the Soviet

38. TASS, Nov. 11, 1981. TASS quoted Danish and United States scientists as saying that, while Uranium-235 and Plutonium-238 are used for the production of nuclear weapons, Uranium-238 "in principle" is not. Id.

39. 1981 FACTS, supra note 15 , at 840 D, E3.

40. For example, on June 16, 1982, TASS reported that the Soviet and Swedish ministers of foreign affairs had met in New York and "declared in favour of developing Soviet-Swedish relations on the foundation of good-neighborliness and in the interest of the people of both countries and the interests of enhancing peace, security and cooperation." TASS, June 16, 1982. Despite official restraint, however, the Swedish media and some representatives of the military establishment speculated about the nationality of the perpetrators and quite openly pointed to the Soviet Union. The Soviet Union ignored these accusations for some time, but eventually Soviet official sources responded by dismissing the "insinuations" as hostile propaganda and "absurd fabrications" orchestrated by Swedish and U.S. militaristic circles in derogation of Sweden's policy of neutrality. Krashnaya Zvezda, Aug. 5, 1982; Radio Moscow (comment in Swedish), Aug. 17, 1982; TASS, Oct. 6, 1982; TASS, Oct. 11, 1982.

41. COMMISSION REPORT, supra note 1, at 41. 
Union charged that the affair had been manipulated by the media to cause a crisis in Swedish-Soviet relations which might serve to justify military spending. ${ }^{42}$ TASS charged that the Commission had failed to offer direct proof of the nationality of the submarines, "rashly" concluding that the vessels were Soviet. ${ }^{43}$

Nevertheless, the Commission Report presented a detailed analysis of the maneuvers allegedly carried out by the Soviet submarines at Harsfjarden and of the likely motives for the intrusions, to which the Soviets made no response. From an examination of the seabed, the Commission Report concluded that both conventional submarines and minisubmarines of both the "keel" and the "track" type had carried out a series of exercises in the Harsfjarden area for a period of at least three weeks. ${ }^{44}$

The Commission judged the primary reason for Sweden's failure to locate the intruding submarines and force them to the surface to be that the Swedes were unable to determine at the time of the Harsfjarden event that they were dealing with minisubmarines, as well as conventional submarines. ${ }^{45}$ The Commission Report found that the weapons and equipment used, which were designed for use against conventional submarines in open waters, as well as the Swedish command, communications, and control systems, were inadequate. ${ }^{46}$ The traditional hydroacoustic equipment used could not cope with the special problems of anti-submarine operations in an archipelago environment with a busy civilian traffic like the Baltic Sea-an environment characterized by shallow water, a rocky and uneven seabed, variations in salinity and temperature, and large amounts of scrap metal on the seabed. ${ }^{47}$ The Report suggested, moreover, that conducting the search in an area readily accessible to the media had also hindered the operation..$^{48}$

42. TASS, April 27, 1983, reprinted in 1983 FACTS ON FILE [hereinafter cited as 1983 FACTS] 336 FG 3.

43. Id.

44. Commission RePORT, supra note 1, at 34-47. The Commission Report concluded that there were six submarines altogether, at least three of which were minisubmarines. Id. The submarines operated in pairs, with a conventional submarine serving as mother craft for each minisubmarine. Id.

45. Id. at 42 .

46. Id.

47. Id. at $45-46$

48. Id. at 43-44. The Commission Report stated:

The geographical location of the operations made it possible for the mass media to follow developments in detail on the spot. This meant that the defense authorities were faced with the time-demanding task of handling a fairly rich flora of rumors and often erroneous material information. In addition, they were required continuously to account for and Id.

justify individual measures within the framework of the operation. 
As for the intruders' motives, the Commission Report suggested that these were most probably to gather intelligence and to test new technology and military strategy, including the use of sabotage troop units and other special forces and preparations connected with the laying and sweeping of mines. ${ }^{49}$

The Commission Report began with the premise that "[i]t is of vital importance to Swedish security policy that Swedish territory be protected by all available means against violations . . . . Confidence in our determination and ability to remain neutral must be maintained." 50 To serve these goals, the Commission concluded, the Swedish defenders at Harsfjarden had legitimately resorted to the use of force. Moreover, the Commission took the view that the response to future intrusions should be even more forceful, to insure that the countermeasures are successful..$^{51}$

This recommendation followed from the Commission's finding that the Swedish forces had shown too much restraint in the Harsfjarden episode, using too few depth charges, for example, to be effective: "It cannot be excluded that some opportunities for effective action . . . could not be fully exploited because of too restrictive firing instructions." 52 The Commission Report did not ignore the hazards of more fully "effective" measures, acknowledging that depth charges "are inevitably blunt anti-submarine weapons, with which it is difficult to distinguish between effective fire for the purpose of forcing the submarine to the surface and fire intended to sink the submarine."53 Moreover:

The step from individual depth charges to multiple drops (on two occasions patterns of four were dropped), like the decision to use mines, was taken in the clear awareness that increased use of fire aimed at forcing submarines to the surface also involved an increasing risk of their being sunk. ${ }^{54}$

Nevertheless, these concerns were overridden, in the Commission's judgment, by military necessity. Thus, the Report concluded that "multiple drops [of depth charges] . . . must generally be tolerated even knowing the risk of an unintentional sinking-if the depth charge, as a weapon, is to have any real effect." 55

In addition to the depth charges, five mines were detonated during the

49. Id. at 74 .

50. Minutes of the Swedish Government, Oct. 21, 1982, quoted in COMMISSION REPORT, supra note 1 , at $7-8$.

51. COMMISSION REPORT, supra note 1, at 81-87.

52. Id. at 51 .

53. Id. at 52 .

54. Id. at 43 .

55. Id. at 52 . 
Harsfjarden operation. The Commission Report acknowledged that it was highly questionable whether it is possible to detonate mines in such a way as to cause controllable, limited damage that will force a submarine to the surface rather than sink it. ${ }^{56}$ According to the Commission Report, the decision of the Commander-in-Chief to use mines in a situation in which the danger of a breakout was judged imminent "was made in the awareness of the risk of doing damage on a scale that could not wholly be foreseen. The Supreme Commander informed the Government to this effect."57

Nevertheless, the Commission Report insisted that the purpose of the use of mines was to force the submarines to the surface and that, consequently, the personnel in charge of detonations "deliberately refrained from automatically detonating mines, and attempted instead a flexible, more sophisticated technique of delayed detonation after indication."58 Despite the unsuccessful Harsfjarden experience, the Commission Report recommended the use of mine barrages in the future to combat alien submarines. $^{59}$

\section{Conflicting Conceptions of Lawfulness}

The legal arguments of Sweden and the Soviet Union centered around three main issues: (1) the violation of territorial sovereignty; (2) the jurisdictional immunity of alien submarines; and (3) the use of force by a coastal state to protect its interests.

\section{A. Violation of Swedish Territory}

The Swedish government viewed the submarine incidents as infringements of Sweden's exclusive right to control access of aliens to the entirety of its territory, including its territorial waters. In the first Swedish statement regarding Karlskrona, the Swedish Minister of Foreign Affairs described the incursion of the Soviet submarine into the restricted military area as a "violation of Swedish territory" and termed its entry into Swedish internal waters without permission from the Swedish authorities a "gross violation of entry regulations" which the Swedish government viewed "very seriously." 60 The intrusion was a "deliberate violation of

56. Id.

57. Id. at 53.

58. Id.

59. Id.

60. RSDS, Oct. 28, 1981; FBIS, supra note 4, at 2 (interview with O. Ullsten). It should be noted that Article 4 of the Swedish Proclamation Concerning the Admission to Swedish Territory of Foreign Naval Vessels and Military Aircraft (1966: 366) provides that craft in distress can enter Swedish territory without authorization or notification. However, the Soviet subma- 
Swedish territory for illegal intelligence aims" made "all the more unacceptable as the submarine was in all likelihood equipped with nuclear charges."61

The Swedish government asserted, therefore, that the territorial violation was aggravated by the high security risk resulting from the presence of the vessel within the restricted military area, the performance of intelligence tasks, and the carrying of nuclear weapons.

The response of the Soviet Union focused on the alleged inadvertance of the intrusion, and did not mention the contravention of Swedish regulations, the entry into a restricted area, or the presence of nuclear arms. ${ }^{62}$ According to the Soviet government, the submarine had no hostile intentions, and thus its presence within Swedish waters "in no way affected Sweden's security interests."63 Therefore, "the Soviet Government resolutely rejected the protest contained in the Swedish Government's statement as devoid of any legal or factual basis."64

By limiting its legal arguments to the absence of hostile intent and the absence of any security risk, the Soviet government avoided engaging in a debate that might undermine principles recognized by its own law, which defend the right of a coastal state to regulate access to its territory. Soviet law does not provide for the general right of innocent passage of alien warships, and requires all foreign vessels passing through its territorial waters to apply thirty days in advance through diplomatic channels for an entry permit, and to comply with its strict regulations. ${ }^{65}$ Submarines allowed to enter Soviet territorial and internal waters must navigate on the surface. ${ }^{66}$ Infringement of either provision by an alien submarine is considered a violation of Soviet sovereignty, and the Soviet Ministry of Defense has issued instructions that a foreign submarine discovered within the state boundaries of the U.S.S.R. while submerged is to be destroyed. ${ }^{67}$

rine was not considered by the Swedish authorities as belonging to this category. See Theutenberg, supra note 2, at 101.

61. AFP, Nov. 5, 1981.

62. 33 Current Dig. Soviet Press, No. 45, at 5 (1981).

63. Id.

64. Id.

65. Articles 16 and 17 of the 1960 Statute on the State Boundary and the 1960 Rules for Visits of Foreign Warships to Territorial Waters and Ports of the U.S.S.R., quoted in W. BuTLER, THE SOVIET UNION AND THE LAW OF THE SEA 52-54, 64 (1971).

66. Id.

67. Barbolia, VoenNo-MorskoI SPRAVochniK 55, quoted in W. Butler, supra note 65 , at 65 . 


\section{B. Jurisdictional Immunity of the Alien Submarine}

Immediately following the events at Karlskrona, the Swedish government instituted an investigation and made the return of the submarine contingent upon its results. It is uncertain whether Sweden ever contemplated the possibility of not returning the vessel or of prosecuting its commander or crew, but there were indications that in this particular case the Swedes were inclined to take stronger action than was usual in such situations. ${ }^{68}$

International law traditionally has afforded the coastal state very little protection in a situation like Karlskrona. Under established practice, if an alien warship does not observe the laws of a coastal state, that state cannot prosecute the offender, but may only complain to the government of the country to which the vessel belongs. ${ }^{69}$ The implication of this rule is that the offense may be punished only by the flag state. The Swedish authorities believed that the submarine found at Karlskrona was probably carrying out a mission ordered by its superiors and directed against Sweden's military installations. Thus, it was their view that a Swedish investigation into the causes of the incident was the only reliable way of protecting Swedish interests. ${ }^{70}$

Anxious to provide a legal justification for its actions, the Swedish Government adopted an interpretation of the law of sovereign immunity that conditioned the immunity of foreign warships within the waters of a coastal state upon compliance with the coastal state's admission regulations. The Legal Adviser of the Ministry for Foreign Affairs stated that Sweden recognizes the principle of state immunity granting foreign stateowned ships immunity from Swedish jurisdiction; however, that immunity is conditioned upon permission to enter the territory. ${ }^{71} \mathrm{~A}$ vessel that disregards admission regulations and flagrantly violates the law of a country cannot be granted immunity in accordance with international law, and the violated state has a right to investigate that vessel's activites in its territory. ${ }^{72}$

According to this view, the traditional hierarchy of principles of the law of the sea, which gives preference to the inclusive interests of the

68. See e.g., RSIS, Oct. 29, 1981 (interview with T. Falldin).

69. See, e.g., Convention on the Territorial Sea and the Contiguous Zone, April 29, 1958, 15 U.S.T. 1606, T.I.A.S. No. 5639, 516 U.N.T.S. 205 [hereinafter cited as 1958 Convention], $\S$ III(c), Art. 23 ("If any warship does not comply with the regulations of the coastal state concerning passage through the territorial sea and disregards any request for compliance which is made to it, the coastal state may require the warship to leave the territorial sea").

70. RSDS, Oct. 29, 1981; Theutenberg, supra note 2, at 102-03.

71. Theutenberg, supra note 2 , at 88.

72. Id. 
international community over exclusive interests of particular participants, is reversed. The justified claim for protection against the possible abuse of the freedom given to alien warships becomes the overriding policy consideration, allowing a coastal state to take actions traditionally prohibited out of concern for freedom of passage.

Understandably enough, the Soviet Union, deviating from its own law, ${ }^{73}$ declared itself unequivocally in support of the customary international rules. After asserting its adherence to the principle of absolute jurisdictional immunity for warships, the Soviet Union defined its acquiescence in the Swedish investigation as "a certain exception" to the general rule dictated by a "spirit of good will" and "the nature of SovietSwedish relations." 74

\section{The Use of Force}

During the Karlskrona episode, the problem of the use of force against the vessel and its commander and crew was not fully discussed by the representatives of the Swedish political elite. The Swedish government did not make any clear declarations as to its intentions. For example, at the press conference during the second day of the affair, Prime Minister Falldin said: "We are prepared to use the naval units we have and other units as well to uphold our territory, but there is no reason to start talking about the use of force now."75 It is reasonable to assume that Sweden did not contemplate any forcible action because there was no real necessity for a resort to force: Sweden could control the situation sufficiently by holding the submarine and its crew hostage. By maintaining some uncertainty as to its intentions, however, Sweden attempted to exert pressure on the Soviet Union and to strengthen its bargaining position in the negotiations. ${ }^{76}$

Increasing submarine violations in 1982 and unsuccessful attempts to capture the perpetrators through peaceful methods changed Sweden's attitude towards the use of force. Prime Minister Falldin and the Minister of Foreign Affairs stated that the Navy's task was to force the alien vessels to the surface in order to identify their nationality, board them, and take them into port for interrogation of the crew. ${ }^{77}$ To achieve this goal,

73. See supra notes $65-67$ and accompanying text.

74. 33 Current Dig. Soviet Press, No. 45, at 7 (1981).

75. RSDS, Oct. 29, 1981.

76. Reportedly, the Minister of Defense was not cautious enough and stated that force would not be considered. This assurance was thought to explain the hardening of the Soviet attitude towards the end of the negotiations. The Times, Nov. 5, 1981.

77. RSDS, Oct. 5, 1982; FBIS (W. Europe), Oct. 6, 1982, at 3-4; AFP, Oct. 6, 1982 (Interview with T. Falldin). 
the Swedish government was ready to resort to armed force. The Commander-in-Chief, commenting on the detonations of mines, said, "it was carried out with the clear intention of seriously damaging a submarine. . . . Exploding the mines in the way we did should reasonably have caused a great deal of damage to a submarine." ${ }^{.78} \mathrm{He}$ also confirmed that the Armed Forces were prepared to repeat the same action in the future, even if the possibility that the crew might die could not be excluded: "There must always be a risk in intruding into Swedish waters," the Commander-in-Chief concluded. 79

The strongest warning and clearest statement of the new policy came from Swedish Prime Minister Palme, who returned to power after six years in opposition on the day of the Harsfjarden mine detonation. At the press conference during which the appointment of the Submarine Defense Commission was announced, the new Prime Minister said:

The Swedish Government has the option of ordering the military to sink a foreign submarine in Swedish waters. Whoever is considering a violation of Swedish territory must take into account that the Government will in future use this option. . . . There are greater possibilities to sink a submarine than to expel it or to force it to surface. ${ }^{80}$

Sweden's threat to sink foreign submarines in peacetime seemed to have no effect on Soviet-Swedish relations. The Soviet Union did not break international silence on this subject, and appeared to join other members of the international community in implicit tolerance of the Swedish policy. This tolerance may be construed as acquiescence in the self-defense argument underlying the new Swedish policy, formulated most explicitly by the Commission Report, which based its appraisal of the lawfulness of the Harsfjarden operation on Chapter 10, Article 9 of the Swedish Instrument of Government, establishing the Government's responsibility for defending the territory against violations by foreign powers: "The Government may authorize the defense forces to use force in accordance with international law and custom for the purpose of preventing any violation of the territory of the Realm in times of peace, or during a war between foreign states." 81 The Commission Report based this assertion on the right of self-defense embodied in Article 51 of the United Nations Charter, which entitles every state, in the words of the Commission, to defend its sovereignty and its territory, if necessary by

78. RSIS, Oct. 13, 1982; FBIS (W. Europe), Oct. 14, 1982, at 2.

79. Id.

80. RSDS, Oct. 22, 1982; FBIS (W. Europe), Oct. 25, 1982, at 1-2 (Press conference).

81. COMMISSION REPORT, supra note 1, at 78. 
recourse "to arms." 82 Consequently, the Commission concluded, "measures taken in accordance with the right of self-defense cannot be regarded as aggression." 83

\section{Outcome}

On July 17, 1982, the Swedish Government published an "Ordinance Containing Instructions for the Armed Forces in Times of Peace and in State of Neutrality,"84 which replaced General Order 48/1967 and entered into force on July 1, 1983.85

The evolution of the Swedish law reflects the changes in behavior caused by the frequency and gravity of submarine violations. The 1967 General Order had stated that the purpose of any action taken by the Armed Forces against an intruding alien submarine was to turn it away from Swedish territory to the high seas. Section 15 of the Ordinance read as follows:

A foreign submarine which is found submerged within Swedish internal waters shall be forced to surface. It shall then be ordered to stop, be identified, and then taken to an anchorage for further action. If necessary, force of arms may be used. A foreign submarine which is found submerged within the territorial sea shall be turned away from the territory. If necessary, force of arms may be used. Should special circumstances so require, the Supreme Commander may order recourse to force of arms without prior warning against a foreign submarine which is found submerged within Swedish waters. ${ }^{86}$

The consistent increase in the number of submarine intrusions coupled with the more openly provocative behavior of the intruding submarines, their more frequent operation within Swedish internal waters and restricted military areas, and their refusal to allow themselves to be turned away, induced the Submarine Defense Commission to recommend further tightening of the 1982 Ordinance. ${ }^{87}$ Its proposals were adopted by the government on March 3,1983.88 Section 15 now reads as follows:

82. Id.

83. Id. The self-defense argument in favor of a forceful action against a "spying" warship also was advanced by some writers. See, e.g., Delupis, Foreign Warships and Immunity for Espionage, 78 AM. J. INT'L L. $72-75$ (1984).

84. COMMISSION REPORT, supra note 1, at 79.

85. The long period between the adoption and entry into force of the act was due to the need for comprehensive amendment of the detailed regulations promulgated by the Commander-in-Chief under the previous General Order. The delay also permitted translation and appropriate publication of the new rules abroad. Id. at 79.

86. Id. at 79-80.

87. Id. at 81-82.

88. Id. at 82 . 
A foreign submarine which is found submerged within Swedish internal waters shall be forced to surface. It shall then be ordered to stop, be identified and be taken to an anchorage for further action. If necessary, force of arms shall be used without prior warning. A foreign submarine which is found submerged within the territorial sea shall be turned away from the territory. If necessary, force of arms shall be used. Should special circumstances so require, the force of arms may be used without prior warning pursuant to a decision by the Supreme Commander. ${ }^{89}$

Thus, the new law authorizes the use of force without warning as a rule rather than as an exception. In explaining the motives for this change, the Commission stated its view that it is impossible for an alien submarine to navigate into Swedish internal waters by'mistake. According to the Commission, Sweden's twelve-mile territorial sea insures that:

if an alien submarine is found in Swedish internal waters, it can be stated with confidence, that both its commander and those who gave the order for its mission are well aware of the submarine's forbidden position and purpose. No warning is required to inform the parties concerned. The same circumstance emphasizes also the extreme improbability of a submarine crew allowing itself to be forced to the surface merely by warning shots. ${ }^{90}$

The Commission's opinion was that, in practice, the warnings merely facilitated evasive maneuvers. ${ }^{91}$

The lesson gained from the operational experience at Harsfjarden was that, in order to be effective, these new rules had to be matched by improved methods of anti-submarine defense. Since 1958, the Navy's share of military spending had decreased from $18 \%$ to $13 \%$, despite the clear shift in emphasis toward naval units elsewhere.92 After the Karlskrona event, the Swedish media and the Armed Forces demanded more effective defense against violations of Swedish territory. The special review of anti-submarine defense resources resulted in a 200 million kroner package, which formed part of the 1982 Defense Act and was meant to improve surveillance, location, and weaponry employed in anti-submarine actions. ${ }^{93}$ Although the main emphasis was on new surveillance and location programs, the new weaponry developed and acquired by the Swedish Navy is the most important aspect of this defense program from the standpoint of international law.

The two most significant weaponry developments were incident depth charges (ELMAs) and anti-submarine torpedos. ELMAs, which are

89. Id.

90. Id. at 84 .

91. Id.

92. RSIS, Feb. 3, 1982.

93. COMMISSION REPORT, supra note 1 , at 90. 
used primarily by patrol boats and missile boat units, are designed to create numerous scattered punctures in a submarine's hull that are not big enough to sink the submarine immediately, but that make immediate repair impossible, so that the submarine is forced to the surface without harming the crew. ${ }^{94}$ The chance of preserving human life in these circumstances, of course, depends upon the capacity of the vessel to surface as quickly as possible. The new anti-submarine torpedo, which is intended for use by helicopters, missile boats, and submarines, has an explosive head designed to destroy the submarine's screw, thereby impairing its maneuvering capacity..$^{95}$

In addition, the Swedes installed a new permanent underwater surveillance system for certain key areas, which is supplemented by a controlled mine system. The number of mines is being increased and they are being modernized. ${ }^{96}$

The development of a surveillance system and the "incident weapons" shows how the events at Karlskrona and Harsfjarden, particularly the latter, influenced Swedish concepts of anti-submarine defense. Before these events, Sweden was not prepared, either in terms of resources or in policy and strategy terms, to deal with submarine violations. The events of 1981-82 brought about a new policy of forcing submarines to surface, when possible, without causing loss of life. At that time, however, the resources needed to implement that policy were not available. To put it bluntly, even if a submarine could have been located precisely, the Swedish Navy had only two choices: to sink and destroy the vessel with its crew, or to let it go. The high probability of casualties, on the one hand, coupled with the need to demonstrate Sweden's determination to stop the intrusions, on the other, explains in part the confusion and hesitancy of the command and control systems which sought to cope with the submarine intrusions. Sweden's development of the "incident weapons" apparently resolved this dilemma. From the Swedish point of view, these weapons represent a rational, balanced response to both the security risk caused by the violations and the difficulty of preventing them, and a way of maintaining the credibility of their policy of neutrality. From the standpoint of international ocean-users, however, they constitute an unprecedented threat to underwater peacetime navigation in foreign waters.

94. RSIS, Feb. 3, 1982; see CoMmISSION REPORT, supra note 1, at 83.

95. COMMISSION REPORT, supra note 1 , at 83.

96. Id. at 93; Svenska Dagbladet, Nov. 28, 1981. 


\section{International Appraisal}

The submarine incident provoked the strongest reaction in the Scandinavian countries. During the events at Karlskrona, the ministers of foreign affairs of Denmark and Norway held a joint press conference, on November 6, 1981, in which they condemned the violation of Swedish territory by the Soviet submarine, and particularly the presence of nuclear weapons on board. ${ }^{97}$ The Norwegian minister warned that if a similar violation occurred in Norwegian waters, the authorities would use depth charges. ${ }^{98}$ The governments of Norway, Denmark, and Iceland ordered their ambassadors to the U.S.S.R. to boycott the annual celebration of the October Revolution as a protest against the presence of nuclear torpedos on board the submarine. ${ }^{99}$ Only the Finnish Ministry of Foreign Affairs failed to express protest, limiting itself to a remark that the submarine affair was regrettable, but that it concerned solely Sweden and the Soviet Union. ${ }^{100}$

The governments of the other Western countries did not speak out. The silence of the major powers can probably be explained by the difficult configuration of interests at stake. On the one hand, a flagrant violation of the territorial sovereignty of Sweden called for condemnation of the Soviet intrusion in Karlskrona. On the other hand, Sweden's determination to stop such incidents, even at the cost of infringing upon the principles of the law of the sea, gave rise to some apprehension. For some naval powers, the affair was a reminder that they could easily find themselves in the Soviets' predicament. ${ }^{101}$

The People's Republic of China was not so reticent, and seized upon the occasion of the Karlskrona affair to accuse the Soviet Union of duplicity in supporting Western European nuclear disarmament movements while intruding into Swedish territory with a nuclear-armed submarine. ${ }^{102}$

The Karlskrona event was brought to the attention of the participants in the Madrid Conference on Security and Cooperation in Europe. The chief Swedish delegate stated that the Soviet Union had violated the Helsinki Act of 1975. The Soviet delegation responded to this accusation by repeating the official version of the incident, and the matter was not dis-

97. Berlinske Tidende, Nov. 7, 1981.

98. Id.

99. N.Y. Times, Nov. 8, 1981, at 3, col. 4.

100. RSDS, Nov. 6, 1981.

101. It is presumably out of such considerations that during the Pueblo incident the Soviet Union refrained from publicizing the affair and commenting on its legal implications. See Butler, The Pueblo Crisis: Some Legal Reflections, 63 PRoc. AM. Soc. INT'L L. 7-8 (1969).

102. N.Y. Times, Nov. 9, 1981, at A5, col. 1. 
cussed further. ${ }^{103}$

During the search for submarines in Harsfjarden, the Swedish Minister of Foreign Affairs, speaking in the United Nations General Assembly, said that "Swedish territory will be protected from violations with all available means." 104 Emphasizing the Swedish policy of neutrality, L. Bodstrom added that "such violations will be treated with equal determination no matter where they emanate from." 105 As with Karlskrona, the international community neither questioned nor condemned the Swedish actions. The international media reported both events in a manner generally sympathetic to the Swedish government's actions.

\section{Writer's Appraisal}

Swedish policy was approved of by some states (Norway and Denmark) and tolerated by other members of the international community, many of whom face similar problems as coastal states (for instance, Argentina, Italy, and Japan). Norway adopted rules permitting the use of force against intruding alien submarines. ${ }^{106}$ No member of the international community protested the new Swedish policy. ${ }^{107}$ Taking into account the great publicity given to the incident and the careful mutual monitoring by international actors, this silence can only be interpreted as acquiescence.

The acceptance of Swedish actions by the world community, notwithstanding their apparent incongruence with well-established international practice, is only partly explained by the special circumstances in which Sweden found itself. It must also be assumed that international elites were aware that, by tacitly approving of the Swedish behavior, they were acquiescing not only in a justified case of self-defense, but also in the erosion of a long-standing principle of international law.

The international norm of jurisdictional immunity for foreign warships, itself unequivocal under customary international law, must be considered in the context of rules pertaining to the control of coastal states over access to their territory, an area in which international law is equivocal and which has undergone a number of recent changes. These changes seem aimed at enhancing protection of the security interests of

103. RSDS, Nov. 10, 1981; FBIS (W. Europe), Nov. 12, 1981, at 4.

104. N.Y. Times, Oct. 16, 1982, at A2, col. 6 .

105. Id.

106. Press \& Information Department, Royal Ministry of Defense, Foreign SubMARINES IN NoRWEgIAN WATERS 1, 8 (Fact Sheet No. 0383, May 1983).

107. The U.S.S.R. did break off ministerial-level relations after publication of the Commission's Report; however these relations are clearly on the mend. See, e.g., N.Y. Times, Mar. 31, 1984, at A2, col. 3. 
coastal states at the expense of the competence of other users of the oceans. A brief examination of this context may be useful in explaining the international reaction to the new Swedish policy.

The centuries-old principle of freedom of navigation is animated by a conviction that only "a minimum of monopolization of either use or authority" over the oceans "can create the greatest net gains both in the ... value of general security and the . . . values of wealth, enlightenment, well-being and so on."108 This principle implies a right of passage of alien ships through the territorial sea of a coastal state. However, there has been, and to a certain extent still is, doubt as to whether the principle of freedom of navigation should imply the right of passage in peacetime of foreign warships. Some states share an opinion, expressed most eloquently by Professor Hall, that the passage of warships has different functions than transit of merchant ships, and constitutes an imminent threat to the security of the coastal state. Hence, the coastal state has the right to regulate the passage of warships by requiring that the foreign warship obtain an authorization or at least notify the coastal state of its intention to pass. ${ }^{109}$

Many states, however, contend that the right of passage in peacetime has been recognized from time immemorial as one of the fundamental principles of the law of the sea. Oppenheim states:

in practice no State actually opposes in time of peace the passage of foreign men-of-war and other public vessels through its maritime belt. It may safely be stated, first, that a usage has grown up by which such passage, if in every way inoffensive and without danger, shall not be denied in time of peace; and, secondly, that it is now a customary rule of International Law that the right of passage through such parts of the maritime belt as form

108. M. McDougal \& J. Burke, The Public Order of the Oceans 562 (1962).

109. Professor Hall states that:

The right of innocent passage does not extend to vessels of war. Its possession by them could not be explained upon the ground by which commercial passage is justified. The interests of the whole world are concerned in the possession of the utmost liberty of navigation for the purpose of trade by the vessels of all states. But no general interests are necessary or commonly involved in the possession by a state of a right to navigate the waters of other states with its ships of war. Such a privilege is to the advantage only of the individual state; it may often be injurious to third states; and it may sometimes be dangerous to the proprietor of the waters used. A state has therefore always the right to refuse access to its territorial waters to the armed vessels of other states, if it wishes to do so.

W. HALL, INTERNATIONAL LAW 198 (P. Higgins 8th ed. 1924). The same argument was made by Elihu Root on behalf of the United States in the North Atlantic Coast Fisheries Case: "Warships may not pass and repass . . . because they threaten. Merchant ships may pass and repass because they do not threaten." 11 Proceedings in the North Atlantic Coast Fisheries Arbitration 2007 (1912). See P. Jessup, THE LAW OF TERRITORIAL WATERS AND MARITIME JuRISDICTION 120 (1927); G. GIDEL, Le DRoIt INTERNATIONAL PUBLIC 284 (1934); Soviet writers quoted by W. BUTLER, supra note 65 , at 59 et seq. 
part of the highways for international traffic cannot be denied to foreign men-of-war. ${ }^{110}$

The 1958 Convention on the Territorial Sea and the Contiguous Zone (1958 Convention) provides for the right of innocent passage of all ships through the territorial sea, ${ }^{111}$ but some states advocated a denial of this right to warships and made reservations accordingly. ${ }^{112}$ Although the 1982 United Nations Convention on the Law of the Sea (LOS Convention) followed the path set by the 1958 Convention in granting the right of innocent passage to all ships, ${ }^{113}$ the controversy concerning warships was not extinguished and the uncertainty as to the existence of a general consensus among states concerning the matter was not dispelled. ${ }^{114}$ The frequent practice is that a coastal state regularly accords passage to foreign warships, but reserves the right to regulate and even to forbid such passage. ${ }^{115}$ In this situation, the question of whether the passage of foreign warships through territorial waters other than straits 116 is a matter of right accorded the flag state, or a matter of tolerance by the coastal state, remains open.

Once a foreign warship is within territorial waters, it enjoys full immu-

110. L. OPPENheim, INTERNATIONAL LAW 494 (Lauterpacht 8th ed. 1955); cf. C. COLOMBOS, THE INTERNATIONAL LAW OF THE SEA 237 (5th ed. 1962); 1 E. BRUEL, INTERNATIONAL STRAITS 230 (1947) (although the right of innocent passage of warships cannot be assumed to exist, such a right is accorded to them in practice by all states in time of peace); 1 D. O'CONNELl, INTERNATIONAL LAW OF THE SEA 274-76 (1982); Froman, Uncharted Waters: Non-innocent Passage of Warships in the Territorial Sea, 21 SAN DIEGo L. REV. 630-46 (1984).

111. 1958 Convention, supra note 69, § III, art. 14(1).

112. M. MCDovgal \& J. BuRKE, supra note 108, at 218-20. Sweden is not a party to the 1958 Convention.

113. United Nations Convention on the Law of the Sea, opened for signature Dec. 10, 1982, U.N. Doc. A/CONF.62/122 [hereinafter cited as LOS Convention], art. 17. Sweden is a signatory to the LOS Convention.

114. Froman, supra note 110, at 639-42 (summary of debates at the Third U.N. Conference on the Law of the Sea).

115. For the history of state practice, see generally D. O'CONNELL, supra note 110, at 277 81. Approximately 50 states support the right of the coastal state to require notification or authorization. Froman, supra note 110, at 651-54.

116. The International Court of Justice held in the Corfu Channel Case (United Kingdom v. Albania), 1949 I.C.J. 4, that a coastal state may not prohibit innocent passage of warships through its straits in time of peace. Id. at 29. See M. MCDougAL \& J. BurKE, supra note 108, at 5469, 202. In Judge Azevedo's dissent in Corfu Channel, however, after having quoted the authorities denying a right of passage to warships, he stated: "To sum up, it is evident that all the arguments invoked in favour of freedom of passage for warships are clouded in confusion, at any rate sufficiently to bar the recognition of a custom in accordance with traditional requirements." 1949 I.C.J. at 101. (Azevedo, J., dissenting). See also G. GIDEL, supra note 109, at 283-84. The confusion concerning the regime of straits was not totally dispelled by the LOS Convention. See Reisman, The Regime of Straits and National Security: An Appraisal of International Law Making, 74 AM. J. INT'L L. 48 (1980); Moore, The Regime of Straits and the Third United Nations Conference on the Law of the Sea, 74 AM. J. INT'L L. 77 (1980). 
nity from the jurisdiction of any state except its flag state. ${ }^{117}$ This principle, being a direct offshoot of the doctrine of the sovereign immunity of states, has an exceptionally strong grounding in customary international law. It guarantees that a foreign warship cannot be seized, that no official of the coastal state can board the vessel without the permission of the commander of the ship, and that no judicial proceedings can be brought against the officers and crew. ${ }^{118}$ The only protection customary international law gives a coastal state against possible abuses of the immunity privilege is the requirement that the vessel comply with the coastal state's regulations concerning the admission of foreign warships to its waters. ${ }^{119}$ If, however, the warship fails to observe these regulations, the coastal state's response is limited to a complaint lodged with the flag state. ${ }^{120}$ If the violation persists, the coastal state can only require the vessel to leave its waters. ${ }^{121}$ This norm was confirmed by both the 1958 Convention ${ }^{122}$ and the LOS Convention. ${ }^{123}$ Unlike the rules regarding right of passage, which distinguish between territorial and internal waters, leaving to the coastal state the exclusive competence to regulate access to its internal waters, the rules concerning jurisdictional immunity apply indiscriminately, notwithstanding the location of the warship. ${ }^{124}$

The policy with respect to the rights of foreign warships first crystallized at a time when a few naval powers were the only effective decisionmakers in the international community. While serving an important inclusive interest, this policy nevertheless primarily benefited those major naval powers that had the means to enjoy such freedom through deployment of their warships throughout the world, to the detriment of the interests of coastal states. From the perspective of the coastal states, warships are a weapon of power politics-symbols and instruments of coercive action that pose a threat to their security. The fear of this threat has stimulated some of these states to react violently in the past. ${ }^{125}$

The development of electronic intelligence gathering and surveillance,

117. C. Colombos, supra note 110 , at 241. Colombos notes, however, that the original entry of the foreign warship must have been expressly or impliedly permitted by the coastal state. Id.

118. Id. at $241-42$.

119. Id. at 242 .

120. Id.

121. Id.

122. 1958 Convention, supra note 69, § III art. 23.

123. LOS Convention, supra note 113, art. 30.

124. This conclusion seems to be consistent with the lack of such a distinction in customary international law and the scholarly writings.

125. Some examples are the 1946 incident in the Corfu Channel (Albania and the United Kingdom), the 1964 incident in the Gulf of Tonkin (the United States and North Korea), and the 1967 U.S.S. Liberty incident (the United States and Israel). 
which in peacetime operate, inter alia, from warships, made the problem more acute. For the coastal states, which often do not have adequate means to counter this sort of activity, intelligence operations within their waters can be seen as violations of their rights and a serious risk to their security. ${ }^{126}$ On the other hand, almost all states are involved in some form of intelligence-gathering, which is deemed indispensable to rational decisionmaking and deterrence. ${ }^{127}$

Claims to enhanced protection of the rights of coastal states induced certain restrictions on the right of passage. In the 1958 Convention, coastal states claimed competence to decide whether a passage of a foreign ship through their territorial waters was innocent-that is, "not prejudicial to the peace, good order or security of the coastal state"128_ and to prevent passage which was not innocent. ${ }^{129}$

The general, abstract terms in which these provisions were worded gave the coastal state wide discretion to interpret and apply them in a way which might be detrimental to the inclusive interests of the international community. Hence; there was widespread opinion that a prescription on innocent passage should be formulated "with maximum precision and certainty of reference." 130 The EOS Convention attempted to restrain the discretion of coastal states by providing an exhaustive list of criteria for evaluating whether a passage is prejudicial to the peace, good order, and security of the coastal state. ${ }^{131}$

Although this provision limits the discretion of the coastal states, its scope is wide enough to permit them to regulate navigation in their territorial seas. A tendency to enhance the protection of their interests may be discerned, particularly in the regulation of the passage of submarines.

126. At least one writer considers the gathering of secret information by a warship in the internal waters of a foreign state to be an act.contrary to international law. See Delupis, supra note 83, at 69. Cf. Fitzmaurice, The Law and Procedure of the International Court of Justice: General Principles and Substantive Law, 27 BRIT. Y.B. INT'L L. 29 (1950) (commenting on the Corfu Channel decision: "It is an inference from certain of the Court's observations. . . that if the motive were espionage, e.g., the observation of the coastal defenses, the passage would not rank as innocent").

127. McDougal, Lasswell \& Reisman, The Intelligence Function and World Public Order, in INTERNATIONAL LAW ESSAYS: A SUPPLEMENT TO INTERNATIONAL LAW IN CONTEMPORARY PERSPECTIVe 311 (M. McDougal \& W. Reisman eds. 1981) ("the gathering of intelligence within the territorial confines of another state is not, in and of itself, contrary to international law unless it contravenes policies of the world constitutive process according support to protected features of internal public order"). But cf. id. at 310 n.53.

128. 1958 Convention, supra note 69 , art. 14(4).

129. Id. art. 16.

130. Burke, Contemporary Law of the Sea: Transportation, Communication and Flight, 2 YALE STUD. WORLD PUB. ORDER 210 (1976).

131. LOS Convention, supra note 113, art. 19(2). 
Both the 1958 Convention ${ }^{132}$ and the LOS Convention ${ }^{133}$ require submarines passing through territorial waters to navigate on the surface and to show their flag. In other words, submerged passage is considered prejudicial to the interests of coastal states, which are under-standably apprehensive about "the use of their territory, without their notice or knowledge, by foreign military craft of great strategic and tactical importance."134 On the other hand, requiring surface passage of submarines may be prejudicial to the security interests of those states employing them, and may aggravate international tensions. ${ }^{135}$ For this reason some states have strongly opposed a requirement of surface passage for submarines.

The assumption underlying the requirement of surface passage - that submergence in territorial waters of a foreign state is tantamount to an exercise of non-innocent passage - is overinclusive, since submerged submarines might be engaged in an innocent passage (that is, one not prejudicial to the peace, good order, and security of the coastal state). Whether a submerged passage is a non-innocent passage must always be a matter of cautious evaluation by the competent authorities of the coastal state: a fortiori, the submerged passage does not give the coastal state a license to use arms against the alleged perpetrator. ${ }^{136}$

The development of rules concerning innocent passage has been accompanied by a gradual extension of the width of internal and territorial waters, thus submitting ever larger portions of the oceans to the exclusive authority of coastal states. It seems, therefore, that in the past few decades the general trend has been towards enhancing protection of the interests of coastal states and, in particular, their claim to security and wealth, even if there are reasonable doubts as to how widely the consensus on some issues is shared. The Swedish policy with respect to submarine violations and the international tolerance of that policy are the most dramatic chapter in this development.

For many centuries, the unimpeded access of foreign warships to territorial waters in peacetime was considered essential to the maintenance of friendly relations among members of the international community and to the improvement of its security through the limitation of tension and conflicts. It is true that unhindered passage of navies through parts of

132. 1958 Convention, supra note 69 , art. 14(6).

133. LOS Convention, supra note 113, art. 20.

134. Burke, supra note 130, at 213.

135. Reisman, supra note 116, at 48-57; D. O'CONNELI, THE INFLUENCE OF LAW ON SEA Power 106-07 (1975); Osgood, U.S. Security Interests in Ocean Law, 1 OCEAN DEv. \& INT'L L. J. 2 (1974).

136. Cf. D. O'CONNELL, supra note 110, at 294-97. 
territorial waters forming straits and other international waterways is of paramount importance to public order, while more extensive restrictions on passage through other parts of the territorial sea, and particularly through internal waters (where coastal states assert an undisputed exclusive competence), are considered justified because international navigation is less likely to be disrupted and important interests of coastal states are involved. If, however, the perceived need for protection leads a coastal state to the general denial of submerged passage in its territorial sea and disregard for the immunity of alien warships found in its internal waters, the likely result will be a destabilizing effect on the security of the international community. This result is particularly likely when the coastal state views itself as justified in using force against such foreign warships. Use of force, even in self-defense, invites use of force.

The Soviet intrusions into Swedish waters clearly demonstrate how the abuse of privileges given by international law leads to the erosion of established norms. While the Swedish response to these incidents may have been reasonable from the Swedish viewpoint, and while it received the acquiescence of the international community, a norm permitting the use of force to repel unauthorized passages of foreign warships in peacetime must be viewed with concern. International law, if it is to mean more than merely naked power, must be based on l'esprit communautaire the common awareness that prudence, self-restraint, and reciprocity are in the long run the best means for maximizing and sharing values in the world community. 